\title{
MEDIATING CIVIL CONFLICTS IN SOUTHEAST ASIA: LESSONS FROM ACEH AND MINDANAO
}

\author{
John Lee Candelaria \\ Graduate School for International Development and Cooperation \\ Hiroshima University \\ jpcandelaria@hiroshima-u.ac.jp
}

Received: $13^{\text {th }}$ August 2020/ Revised: $23^{\text {rd }}$ October 2020/ Accepted: $15^{\text {th }}$ November 2020

How to Cite: Candelaria, J. L. (2020). Mediating Civil Conflicts in Southeast Asia: Lessons from Aceh and Mindanao. Journal of ASEAN Studies, 8(2), 111-127, https:/doi.org/

10.21512/jas.v8i2.6622

\begin{abstract}
Southeast Asia has been a hotbed of intractable civil conflicts motivated by several issues such as ethnicity, ideology, and historical injustice, among others. Despite the intractability, there have been instances when third-party assistance through mediation has been vital in achieving peace agreements in the region. Using the cases of the third-party mediation of the conflicts in Aceh, Indonesia and Mindanao, Philippines, this research identified the kinds of mediation and qualities of mediators that led to the achievement of peace agreements in these two cases. This research mainly focused on path dependence, critical junctures, and periodization approaches in the comparative analysis of Aceh and Mindanao third-party mediation through a qualitative examination that involved comparative process tracing (CPT), a two-step methodological approach that combines theory, chronology, and comparison. The results showed that the mediators instrumental to the Aceh and Mindanao peace agreements allayed the commitment issues of the negotiations and ensured the trust and confidence of the conflict parties. Thus, mediators should create relations of trust among parties and a mediation environment where the commitment fears are relieved through the promise of thirdparty monitoring.
\end{abstract}

Keywords: Mediation, civil conflicts, third-parties, Southeast Asia, Aceh, Mindanao

\section{INTRODUCTION}

Southeast Asia is one of the most ethnically diverse regions of the world. Consequently, it also hosts some of the most protracted civil conflicts in modern times. Between 1993 and 2004, 14 out of 32 low-intensity conflict dyads in Asia are in Southeast Asia, yet there have 
been few formal third-party attempts in the region than the rest of the world (Möller et al., 2007). Among Southeast Asian countries, Indonesia and the Philippines have received the most significant number of formal third-party mediation attempts (Derouen \& Bercovitch, 2019), which have resulted in relative success and the signing of peace agreements instrumental to conflict termination. Therefore, the mediation of the protracted Aceh and Mindanao conflicts could serve as exemplars of third-party mediation success.

The conflicts in Aceh and Mindanao have individual contexts yet share some similarities. The Free Aceh Movement (Gerakan Aceh Merdeka or GAM) in Indonesia and the Moro National Liberation Front (MNLF), and later on, the Moro Islamic Liberation Front (MILF) in the Philippines claim to fight for their historical grievances rooted in a distinct identity that formed the foundation of their call for separation. Both conflicts lasted for multiple decades, with their respective governments being initially reluctant to accept third-party involvement. On the other hand, the conflicts were mediated with a variety of strategies and actors. These conflicts have also been a subject to investigation and analysis of many scholars, as either individual or comparative cases.

This research seeks to understand how the third-party mediation of Aceh and Mindanao peace processes led to peace agreements. These cases were mainly chosen since they stand out among mediation efforts in the region. Non-state actors, i.e., nongovernmental organizations or NGOs (the Henry Dunant Centre or the HDC and the Crisis Management Initiative or the CMI), mediated the Aceh conflict. In contrast, the Mindanao conflict was mediated by an intergovernmental organization or IGO (the Organization of the Islamic Conference or OIC) and later a neighboring state (Malaysia). The varying actor types provide an opportunity to explore how NGOs, IGOs, and states could serve as third-party mediators, while the differing lengths of conflict interventions provide a nuanced analysis of how mediator strategies affected the success of third-party mediation. These mediation episodes of the peace processes were analyzed through a qualitative examination that involves comparative process tracing (CPT), a two-step methodological approach that combines theory, chronology, and comparison, whose logic could be relevant in comparing fast-moving political processes such as peace negotiations (Bengtsson \& Ruonavaara, 2017). This research mainly focuses on path dependence, critical junctures, and periodization approaches in the comparative analysis of Aceh and Mindanao third-party mediation using CPT.

\section{LITERATURE REVIEW}

\section{Third-Party Mediation}

Bercovitch defines mediation as "a process of conflict management, related to but distinct from the parties' own negotiations, where those in conflict seek the assistance of or accept an offer of help from an outsider to change their perceptions or behavior and to do so without resorting to physical force or invoking the authority of the law" (2008, p. 343). The mediation situation is comprised of parties to the conflict, a mediator, a process of mediation, and the context of mediation. 


\section{Effectiveness of mediation}

In assessing the literature on how mediation helps secure peace, Beardsley (2008) observed a lack of consensus on mediation's long-term effect on peace but contended that mediation positively influenced short-term outcomes of conflict management. The extant literature on mediation, therefore, focuses on these immediate and short-term gains. In identifying factors for mediation success, Haass (1990) considered the following as prerequisites: 1) a mutual desire for an accord, 2) a formula with benefits for all parties, 3) a negotiating process that is acceptable to all, and 4) a leadership strong enough to maintain compromise. Kleiboer (1996), on the other hand, identified four factors associated with mediation success, namely: 1) characteristics of dispute, 2) characteristics of the mediator, 3) the interrelationship among the parties, and 4) the international context.

Mediators perform at least three important roles, according to Touval and Zartman (1985). The first is informational: mediators can supply missing information, transmit messages, highlight common interests, and encourage meaningful communication so that combatants can better locate common middle ground. The second is an essential procedural role as they arrange for interactions between the parties, control the meetings' pace and formality, and structure the agenda to keep the process focused on issues. The third role is, in some ways, more coercive. Mediators can reward the parties' concessions and punish intransigence for making disagreement costly (Walter, 2002).

\section{Mediator actors}

Mediator types and their position relative to the conflict parties have been widely explored in mediation literature. Traditionally, a third-party mediator is a neutral outsider, and neutrality has been regarded as a necessary tool for the successful mediator (Carnevale \& Arad, 1996; Young, 1967). Smith and Stam (2003) argued that to earn the designation of a genuine, honest broker, a mediator must be unbiased and not prefer outcomes that favor one side to the other. Equally important, it must not have an aversion to war. Nevertheless, mediator impartiality has been hotly debated by scholars. An essential work by Lederach (1991) found that instead of neutrality, conflict parties seek trust and confidence from mediators. This work was further expanded by Wehr and Lederach (1991), who suggested that insider-partial mediators, i.e., mediators from within the conflict, embody trust and confidence, whose acceptability is rooted not in the distance from the conflict but instead in connectedness and trusted relationships with the conflict parties. Insider-partials also have a stake in the conflict outcome and will have to live with the consequence of their mediation. The trust and confidence that conflict parties feel for an insider mediator is not because of the perception of neutrality, but rather the inherent knowledge and connections the mediator has about the conflict parties. Wehr and Lederach contended that this type of mediator would work well in conflicts where parties rely heavily on interpersonal trust and personal relationships, complementing outsiderneutral mediators. 
Elgström, Bercovitch, and Skau (2003) expanded on the concept of mediator partiality by identifying three possible meanings attributed to the concept: 1) relational partiality, which rests in the closeness and previous ties a mediator has to the disputants; 2) processual partiality, where the mediator favors one party during the negotiation process by listening more closely to that party; and 3) outcome partiality, where the mediator deliberately favors one of the parties in its proposal for settlements.

\section{International mediation in Indonesia and the Philippines}

Studies on the mediation of Aceh and Mindanao conflicts also zoned in on the mediation effectiveness and mediator types. Huber (2004) investigated the role of the Henry Dunant Centre (HDC) in the Aceh conflict and identified three emerging themes: 1) while political dynamics in Indonesia was significantly shifting, it was not certain if the conflict was "ripe" and truly amenable for resolution; 2) the HDC was confronted with the limits of what an NGO could do to achieve a successful accord while lacking formal power; and 3) the HDC may have chosen not to address several issues that could have led to more successful ends. Heiling (2008), on the other hand, credited the success of the Aceh mediation to procedural factors such as mediation behavior and mediation strategies employed by the CMI, and their use of contacts with official track one actors, all of which were crucial in securing the signing and implementation of the peace accord. Furthermore, Higgins and Daly (2010) pointed out that while the devastating tsunami signaled the impetus for improving the negotiation parties' commitment, it is still the mediator who ensured a successful peace deal. Shea (2016) echoed the same findings, attributing the success of the peace process to the characteristics of the CMI as a mediator despite their apparent limitation being a small NGO.

More in-depth research on the Mindanao conflict mediation was also carried out, such as the work of Fitrah (2012), who argued that in the context of the multiparty mediation of the Mindanao conflict, mediators with higher standing, i.e., those that are well-coordinated and supported by the power and status of the organization are more likely to succeed in helping the parties come into a peace agreement. In comparing the mediation of the Government of the Republic of the Philippines (GRP) and the MNLF to the then ongoing GRP-MILF, Fitrah noted that unlike the OIC, Malaysia had limited influence over the negotiations. Malaysia's role as mediator was further investigated by na Thalang (2017). In comparing the country's involvement in the Southern Thailand and Mindanao conflicts, the research argued that various developments had paved the way for Malaysia to play a more decisive role in the Mindanao conflict, which was attributed to the Philippine government's openness towards third-party involvement, regional security concerns, and less-polarized politics. On the other hand, Taya et al. (2018) offered insights in comparing the Mindanao conflict mediation by OIC and Malaysia, which differed on their peacebuilding models. They argued that Malaysia's thirdparty involvement model is more successful because it was not confrontational, and unlike the OIC, Malaysia's "quiet diplomacy" brought a positive impact to the conflict mediation.

Some studies examined the Aceh and Mindanao conflicts by employing a comparative approach, such as Harish (2005) and Odaira (2009), whose analysis showed that it is not the 
mediator's impartiality that mattered, but the leverage it had over the disputants. Buendia (2005) investigated the two conflicts to gain lessons that could be valuable for conflict resolution. He argued, among others, that while the peace process was arduous, it remained the only sensible means and that painstaking confidence-building measures and dialogue that deal with the core problems of the feuding parties were imperative for success. Sangsuwan (2014) applied comparative framing analysis to explore the conflict and peace process in Aceh and Mindanao and concluded that the success in Aceh is a result of the strong political will of its government leaders and the trust they received from GAM, while the failure of the peace process in Mindanao was attributed to the government's weak political will and lack of trust by the MNLF and the MILF.

These attempts at a comparative analysis of the Aceh and Mindanao conflicts are noteworthy. However, it appears that there has been no comprehensive comparative analysis of conflict mediation that looks at the mediators as actors and the respective strategies they introduce. This research fills that gap at an opportune time-while the Aceh conflict was terminated, and a definitive and durable peace agreement was signed in 2005 (Sustikarini, 2019), the final peace agreement of the Mindanao conflict and the enabling law for its implementation were only achieved in 2014 and 2018, respectively. In light of these developments, the mediation of both conflicts could be revisited to gain new insights on how instrumental mediation became in the signing of peace agreements.

\section{Aceh and Mindanao: Conflict Roots and International Mediation}

The foundation of the Muslim separatist movements in Aceh and Mindanao is the assertion of a religious, cultural, and historical uniqueness, making them distinct from the rest of the population. Thus, their historical grievances, rooted in marginalization and exclusion, formed part of the rebel groups' rationale to seek independence from the government. This section traces the roots of the conflicts, focusing on the rebel groups in Indonesia and the Philippines.

\section{The Free Aceh Movement (Gerakan Aceh Merdeka/GAM)}

While the historical difference of the Acehnese is usually identified as the root of the conflict, it is the Indonesian state's activities that caused the contemporary conflict. In unpacking the Aceh conflict, Miller (2008) explained that the conflict precursors in the 1950s and 1960s led GAM to assert that the state exploited Aceh's resources, broke promises of a special region status for the province, and enabled depredations against the Acehnese by the state military. The 1970s caused Acehnese discontent to resurface after the Indonesian state's centralizing policies through President Suharto's New Order did not fulfill the Acehnese aspiration to restore Islam's dominance in Indonesia, as well as the tightening grip of the central government in the affairs of regional governments. The discovery of vast reserves of oil and natural gas in North Aceh and the growth of a nearby industrial zone fueled further discontent, as profits were siphoned off to the central government without introducing sufficient 
interventions to improve Aceh's local economy. As the industrial zone expanded, nonAcehnese and non-Muslim workers from outside Aceh came in droves, while the villages near the zone were displaced because of the expansion. A large number of Indonesian security forces were also deployed to secure the zone, which further exacerbated the Acehnese's injured feelings as the depredations of the security forces changed the way the Acehnese viewed the Indonesian central government.

On 4 December 1976, Tengku Hasan Muhammad di Tiro, a descendant of precolonial sultans and participant of an earlier rebellion, declared Aceh independence, creating the Gerakan Aceh Merdeka (GAM) or the Free Aceh Movement. The government quickly suppressed GAM, whose leadership fled to Europe. GAM was able to relaunch in 1989, with the Indonesian government launching a brutal counterinsurgency operation that almost immediately obliterated GAM military capabilities but continued until 1998 (Sukma, 2004).

\section{The Moro National Liberation Front and the Moro Islamic Liberation Front}

The Mindanao conflict is identified to have roots from the Spanish colonial period when Muslim Mindanao is not effectively subjugated by Spain, separating them from the rest of the country's development. Spain ceded the Philippines to the United States after 300 years, and the Americans proved more successful in subjugating the Muslims and created the Moro Province to integrate Muslims into the rest of the country. However, the Americans concentrated the state's powers to Luzon's Christianized elites, leaving out the Muslims of the south in the whole project of nation-building while initiating the steady stream of Christian migration to Mindanao.

As the Philippines was granted independence, political power was institutionalized under the Christian majority. Tensions soon arose between the Christians and the Muslims when the government adopted the US resettlement program, resulting in the substantial movement of different groups to Mindanao. The influx of resettlers led to a fight for the region's land and resources, increasing the animosity among Christian resettlers, non-Christian groups, and the Muslims.

Separatism or Muslim nationalism was first expressed through the Moro Independence Movement, founded in 1968 as a reaction to the Jabidah massacre, the massacre of Moro army recruits by the Philippine Armed Forces in the same year. This event is an important turning point because it fueled significant issues within and outside the country. The Moro recruits thought they were training as army recruits, only to find out that they were to be sent to Sabah, Malaysia, to agitate for war since the Philippines claimed the said territory. The Moro recruits were massacred, which angered Muslims in the Philippines and Malaysia. Thus, the MNLF was formed in 1972 by students and politicians. It aimed to create the Bangsamoro Republic (Abinales \& Amoroso, 2017) and was supported to some extent by Malaysia (Che Man, 1990). The Moro Islamic Liberation Front (MILF) took on the role as the standard-bearer of Muslim separatism after the MNLF signed a peace agreement with the government in 1996. 


\section{ANALYSIS \\ Mediators of the Aceh and Mindanao Peace Processes}

Different actors mediated various stages of the conflicts in Aceh and Mindanao. For Aceh, NGOs were instrumental in achieving peace agreements since the Indonesian government preferred non-state actors after the UN intervention in East Timor (Shea, 2016). For the Philippines, the OIC mediated the peace process by forcing conflict parties to negotiate for a peaceful resolution. Later, Malaysia was sought by the Philippine government to mediate, following a disastrous foray into unmediated bilateral talks with the rebel group. This section explores how these different mediators approached the peace processes and the strategies utilized to achieve settlements.

\section{Aceh: The Henry Dunant Centre}

Abdurrahman Wahid, the new Indonesian president in 1999, invited the HDC to mediate between the government and GAM, knowing that the rebel group would be more open to dialogue through an international actor. Thus, choosing an NGO was seen as something that satisfied GAM leadership and the Indonesian government (Kivimäki \& Gorman, 2008). The parties first met in Geneva in January 2000. In a few months, an agreement called the "Joint Understanding on Humanitarian Pause for Aceh" was reached. Also referred to as the Humanitarian Pause, it was essentially a ceasefire while the parties further negotiated. A local security committee consisting of representatives from GAM, the Indonesian army, and the HDC was created to monitor the implementation of the ceasefire. The ceasefire was upheld until January 2001 and not renewed due to the increasing animosity between conflict parties. As a result of the Humanitarian Pause's failure and his weakening political capital, Wahid authorized an all-out security operation against GAM in April 2001. Later in July, Wahid was replaced by Megawati Sukarnoputri.

The HDC pushed on despite the challenges and achieved a breakthrough in 2002. Megawati appointed a popular officer, Lt. Gen. Susilo Bambang Yudhoyono, as coordinating minister for political and security affairs. The dialogue continued in Geneva in February and May. A formal ceasefire agreement, the Cessation of Hostilities Framework Agreement (CoHA), was signed in December 2002 (Merikallio, 2006). While identical in principle with the Humanitarian Pause, the CoHA presented a more comprehensive framework (Braithwaite et al., 2010). The CoHA was achieved through "proximity talks," in which the government and GAM were kept separately, and the HDC shuffling between Jakarta, Banda Aceh, and Stockholm (Huber, 2004). However, the CoHA was short-lived: in a matter of weeks, the agreement unraveled as both parties accused each other of breaking the agreement terms.

\section{Aceh: The Crisis Management Initiative}

Watershed events in 2004 opened opportunities for negotiations to resume. Indonesia held its first-ever presidential elections, and Megawati's minister for political and security 
affairs Yudhoyono was elected president while Yusuf Kalla, also a former minister under Megawati, was elected vice president. Before the elections, Kalla had already initiated informal talks with some moderate Acehnese outside of GAM's leadership in exile and came across the CMI, a small NGO started by former Finland President Martti Ahtisaari. CMI was identified as a potential mediator (Huber, 2008). The informal talks continued after the elections, and by December 2004, Ahtisaari was informed that both sides were ready to negotiate. In the same month, the Indian Ocean earthquake and tsunami struck, bringing destruction and devastation in many areas, especially Aceh.

Negotiations resumed on 27 January 2005 in Helsinki. The Yudhoyono administration was adamant about reaching a comprehensive resolution to the conflict, while GAM was also more open and amenable to finding a resolution as it relinquished its claim for independence (Huber, 2008). This openness was a crucial concession that led to the government permitting the creation of local-level political parties, allowing GAM to be transformed into a non-violent political force.

The Memorandum of Agreement was signed on 15 August 2005. It authorized a more robust third-party to monitor the agreement, which called for a 300-strong force of European Union (EU) and ASEAN personnel, with the CMI Chair, Ahtisaari himself, empowered as the final arbiter of disputes that could not be resolved at lower levels (Huber, 2008).

\section{Mindanao: The Organization of the Islamic Conference}

The OIC was instrumental in bringing the Mindanao conflict parties to the table. It recognized the MNLF's struggle for independence by giving the group an observer status in the conference, while OIC members threatened the Philippine government with sanctions if they refused to negotiate and a peace agreement was not concluded (Fitrah, 2012; Harish, 2005; Taya et al., 2018). In the pre-negotiation phase, the OIC reframed the conflict through a Joint Communique, where the organization called for "a political and peaceful solution... within the framework of the national sovereignty and territorial integrity of the Philippines" (Noble, 1981, p. 1099).

The formal talks mediated by the OIC Committee of Four (Libya, Saudi Arabia, Senegal, and Somalia) happened in Jeddah in January 1975 (Lingga, 2006). The subsequent meetings resulted in the signing of the Tripoli Agreement in Tripoli, Libya, on 23 December 1976. The agreement stipulated ceasefire arrangements and terms of the peace settlement, as well as autonomy for thirteen provinces in Mindanao.

The agreement unraveled quickly, as parties disagreed with implementation. The MNLF rejected how the Philippine government implemented the agreement, and violence reoccurred. Disagreements within the MNLF ranks resulted in the birth of the MILF in 1977, a breakaway faction led by Salamat Hashim.

The MNLF quickly returned to its independence demands. As Marcos was ousted through mass mobilizations in 1986, a new democratic government was ushered in, led by 
President Corazon Aquino. This event provided an opening for the peace talks to resume. The OIC mediated for another peace agreement called the Jeddah Accord signed in 1987. The MNLF once again accepted autonomy but contended that they were "pressured thrice by the OIC to talk with the government" and did not want to accept the autonomy deal in the first place (Marohomsalic, 2001 p. 296).

Challenges to agreement implementation persisted, while the Jeddah Accord's signing also further alienated the MILF since they were not included in the talks. The disagreements resulted in deepening the incompatibilities brought about by varying interpretations of earlier agreements.

The OIC proceeded with its mediation of the peace talks with a new president elected in 1992, Fidel V. Ramos. The original Committee of Four was expanded to six with Bangladesh and Indonesia's inclusion, with the latter taking the leadership role. Four rounds of talks from October 1993 to August 1996 came up with the signing of the Final Peace Agreement (FPA) on 2 September 1996.

\section{Mindanao: Malaysia and the International Contact Group}

With the conclusion of the 1996 FPA, the MILF became the standard-bearer of Muslim independence in the country. Talks between the government and the MILF commenced immediately, this time without a third-party mediator. However, the agreements signed during this period of unmediated negotiations were limited to ceasefires and cessation of hostilities. Clashes between the parties also continued and reached its climax when new President Joseph Estrada declared an "all-out war" in April 2000, while the MILF responded with an "all-out jihad war" (Iqbal, 2018).

In 2001, Malaysia was involved in mediating the peace talks upon the invitation of the newly installed President Gloria Macapagal-Arroyo and the concurrence of the MILF. The positive attitude towards Malaysia by both parties was rooted in the fact that Malaysia, while having a majority Islamic population, also hosts many non-Muslim citizens, an exemplar that Islam can co-exist peacefully with other religions (Fitrah, 2012). MILF peace panel chair Mohagher Iqbal also noted that "the common Malay culture and temperament among the key players...eased facilitation, and [Malaysia's] role made it the constant figure in the ups and downs of the peace process" (Iqbal, 2018).

Nonetheless, Malaysia seemingly had weak leverage in terms of resources, which was remedied through the International Monitoring Team (IMT), a joint military and civil monitoring group deployed since 2005 and composed of Malaysia, Libya, Brunei, Japan, Norway, and the EU; and the International Contact Group (ICG) created in 2009, whose primary role was to ensure implementation of mutually-agreed approaches and was comprised of Japan, United Kingdom, Turkey, and Saudi Arabia with four international NGOs: Muhammadiyah, the Asia Foundation, the HDC, and Conciliation Resources. 
The most contentious aspect of the peace talks at that point was the discussion on the issue of ancestral domain, a territorial issue in the creation of the Bangsamoro Juridical Entity that will exist within national sovereignty. In 2008, the government and the MILF released a joint communique to end the formal talks on the ancestral domain. A Memorandum of Agreement on Ancestral Domain (MOA-AD) called for a referendum for about 700 villages in Mindanao to decide if they want to join the Bangsamoro. Local Christian officials in Mindanao challenged the MOA-AD and asked the Philippine Supreme Court to block the signing of the agreement. Later that year, the Supreme Court declared that the MOA-AD was unconstitutional and illegal, practically dissolving the ongoing peace talks and plunged Mindanao into a severe level of violence that displaced over half a million citizens in the region (Williams, 2010). The peace talks once again stalled.

In 2010, a new Philippine president was elected, Benigno C. Aquino III. He initiated exploratory talks with the MILF in 2011, and the peace talks resumed with Malaysia once again mediating. On 15 October 2012, the parties signed the Framework Agreement on the Bangsamoro (FAB), a significant breakthrough in the sixteen-year negotiations. The agreement called for the creation of a Bangsamoro Government, which would allow Filipino Muslims the authority to regulate on their own. What followed the FAB signing is the incremental progress towards finalizing other terms of the agreement referred to as annexes. On 27 March 2014, the Comprehensive Agreement on the Bangsamoro (CAB) was signed by the parties.

\section{The Insider-Outsider Mediators of the Aceh and Mindanao Peace Processes}

The two conflict cases present an opportunity for analyzing mediators within the insider-outsider mediator typology: the HDC and CMI are NGOs considered to be outsiders to the Aceh conflict, while the OIC and Malaysia are insiders to the Mindanao conflict. This analysis is elaborated in this section.

\section{The outsider mediators: HDC and CMI}

Both NGOs legitimized their position as mediators because they were outsiders perceived to be neutral and impartial. The conflict parties trusted the mediators; however, the mediator (in the HDC case) could not build trust between the conflict parties. On the one hand, the HDC led an ambiguous negotiation that did not actively push for an agreement and did not settle the parties' incompatibilities. On the other hand, the CMI was able to outline at the onset that the negotiation was aimed at an agreement, which resulted in a definitive settlement enabling the signing of an agreement.

The CMI also showed its partiality early on, as Ahtisaari informed GAM that independence is not an option (Heiling, 2008). While this angered GAM, it allowed them to develop a self-government proposal, a workable setup that emanated from their ranks. Ahtisaari also built trust among conflict parties by championing the spirit of compromise - parties must first commit to the process before committing to the agreement (Kingsbury, 2006). 
Ahtisaari also understood the limits of an NGO-led mediation. He believed NGOs should not be responsible for monitoring peace agreements due to their limitations. Bringing the EU and the ASEAN to the Aceh Monitoring Mission proved instrumental in strengthening the parties' trust and confidence in the agreement and bolstering the leverage and legitimacy of the mediation led by CMI.

The conflict parties also praised Ahtisaari's leadership of the mediation. As the lead GAM mediator Malik Mahmoud noted, "Ahtisaari is an exceptionally good intermediary and negotiator. I believe he is also a man who stands behind his word and wants to see the process succeed. I am confident that he will continue to follow it up" (Merikallio, 2006, p. 26). This trust emanated from the mediator's processual partiality to GAM and outcome partiality to the Indonesian government, made apparent by the skillful strategies employed by Ahtisaari.

What is evident in this analysis is that while both the HDC and the CMI were outsiders that could have used their perceived neutrality as leverage, in the end, it was the trust and confidence of the conflict parties to the CMI through Ahtisaari that proved most useful in ensuring the peace agreement.

\section{The insider mediators: OIC and Malaysia}

The Mindanao peace process mediators from 1975 to 2014 could be considered insiders to the conflict. The OIC, as an organization of Islamic states, had an evident religious and cultural proximity to the MNLF. Meanwhile, Malaysia was a close neighbor and ally that had a majority Muslim population.

The OIC mediation of the Mindanao conflict was initiated through coercion, which affected the trust and confidence of the conflict parties in the mediators. The Libya-led OIC mediation that resulted in the Tripoli Agreement and the Jeddah Accord used the OIC's leverage to threaten the Philippine government and entice the MNLF with incentives to participate, eroding the government's commitment to the peace agreement implementation. The dynamics changed when Indonesia led the OIC mediation of the conflict. The conflict parties' trust was secured since the leader was an insider that offered an approach that is uniquely "ASEAN." According to former Philippine President Fidel V. Ramos, "the approach of musyawarah (consultation) and mufakat (consensus) proved to be the most productive" in the achievement of the 1996 FPA (Santos, 2013).

However, the fight for Muslim separatism continued through the MILF. This development could be attributed to the fact that, in the first place, the MNLF did not desire autonomy, and when it finally agreed to it, the breakaway faction that created the MILF already expressed that the fight for independence would continue. The MILF only accepted the autonomy that bore their concurrence, which was evident in the developments that led to the signing of the $2014 \mathrm{CAB}$.

The conflict parties quickly trusted Malaysia because the Philippine government, with MILF concurrence, sought the state's service as a mediator. Their mediation style was focused 
on shuttling between parties to dissolve deadlocks and a more consultative method of resolving incompatibilities. Elaborating on their mediation strategy, Malaysia's chief facilitator Tengku noted: "What we did was, we agreed on the principles and they would discuss them in detail. When I move the principles in, I don't get involved in the discussions... I never issued ultimatums. Nobody can say 'you do this, you do that...' it required lots of compromises and understanding” (Karim, 2012).

While being an insider-impartial mediator, Malaysia lacked leverage when compared to the OIC. The trust and confidence that the conflict parties had in the mediator could quickly be shattered by unexpected events, which materialized when the MOA-AD debacle in 2008 threatened the peace process altogether. The MILF began questioning Malaysia's position as a mediator of the conflict. The entry of the International Contact Group (ICG) as an ad-hoc mediator in 2009 was essential to bolster Malaysia's leverage since the ICG was composed of Japan, the United Kingdom, Turkey, and Saudi Arabia, together with four international NGOs. The ICG entry was instrumental since it introduced hybrid mediation assistance composed of states and NGOs, the first time this configuration was ever attempted. The ICG, together with the IMT, provided clearer monitoring capabilities that renewed the parties' trust in the mediation efforts.

In the mediation of the Mindanao peace process, what mattered more than being insiders was how the mediators used their proximity to the conflict or conflict parties to gain their trust and confidence that led to mediation success.

\section{CONCLUSIONS}

The analysis on the Aceh and Mindanao peace processes presented in this study emphasized the crucial roles of positioning (insider or outsider) and partiality (relational, processual, and outcome) in identifying factors that lead to mediation success. It was found that while both insider and outsider mediators have relative strengths in leading the peace process to a resolution, it can only do so by ensuring the conflict parties' trust and confidence in the mediator, the mediation, and the resulting agreement. Moreover, this research echoed the recommendation of Elgström et al. (2003) on the importance of exhibiting processual impartiality at the least in achieving durable solutions. The CMI and Malaysia mediation showed this level of impartiality by making the conflict parties commit first to the negotiation and set aside contentious points until compromise and concessions were ready to be made.

On mediator actors and approaches in Aceh and Mindanao, this research provided compelling support for mediation and the mediators' role in solving conflict parties' incompatibilities. It is evident that no conflict, however protracted, is invincible from peace efforts such as mediation. However, what matters in achieving a durable peace agreement is how mediators secure the parties' trust and confidence. Such finding could lead us to argue that the kind of mediator is not crucial, whether a state, IGO or NGO, outsider or insider; as long as the strategies they utilize create relations of trust and maintain an environment conducive for allaying commitment fears, they are capable of leading negotiations towards agreements. 
Another critical finding presented in this research is that the limited mediator leverage can always be augmented through international cooperation, which could lead to an upsurge in mediator legitimacy. Both Aceh and Mindanao peace processes involved third parties in the promise of monitoring and enforcement, ranging from state actors, NGOs, and IGOs. As it is true in mediation, third parties as monitors and enforcers might also have the same effect of increasing trust and commitment, this time, in the implementation phase of the process, which could be another research subject in the future.

The realm of conflict resolution is increasingly complex, but various actors, insider or outsider, could explore the strengths they could bring to the negotiation table. In Southeast Asia, the ASEAN has been involved in some peace processes, but only as part of the monitoring team. As a regional intergovernmental association, the ASEAN's potential role as a mediator could be explored. After all, it is in the best interest of regional organizations to take on a conflict management mandate to offer solutions that could aid its members towards its development aims. The ASEAN's potential role as a mediator could be examined by other scholars studying conflicts in the region.

Ultimately, this research showed that while resolving civil conflicts through peace processes and mediation could be arduous, laborious, and excruciatingly slow, the bulk of the work is on the mediator's shoulder. The snags and hurdles of the process could be solved by carefully reevaluating and recalculating strategies aimed at resolving the parties' incompatibilities, building trust in the mediator and the process of mediation, and finding an agreement that parties could commit to credibly.

\section{ABOUT THE AUTHOR}

John Lee Candelaria is a Ph.D. student at the Graduate School for International Development and Cooperation, Hiroshima University, Japan. He finished his BA and MA in History from the University of the Philippines Diliman. His research interests include International Relations, Peace and Conflict Studies, Heritage Studies, and Philippine and Southeast Asian History.

\section{REFERENCES}

Abinales, P. J. and Amoroso, D. J. (2017). State and Society in the Philippines ( $2^{\text {nd }}$ Ed). Lanham, Maryland: Rowman \& Littlefield.

Beardsley, K. (2008). Agreement without peace? International mediation and time inconsistency problems. American Journal of Political Science, 52(4), 723-740. https://doi.org/10.1111/j.1540-5907.2008.00339.x 
Bengtsson, B. and Ruonavaara, H. (2017). Comparative process tracing: Making historical comparison structured and focused. Philosophy of Social Sciences, 47(1), 44-66. https://doi.org/10.1177/0048393116658549

Bercovitch, J. (2008). Mediation and conflict resolution. In J. Bercovitch, V. Kremenyuk, \& I. W. Zartman (Eds.), The SAGE handbook of conflict resolution (pp. 340-357). London: SAGE.

Braithwaite, J., Braithwaite, V., Cookson, M. and Dunn, L. (2010). Anomie and Violence: Non-truth and Reconciliation in Indonesian Peacebuilding. Canberra: Australian National University Press, The Australian National University. https://press.anu.edu.au/publications/series/peacebuilding-compared/anomie-andviolence

Buendia, R. G. (2005). The secessionist movement and the peace process in the Philippines and Indonesia: The case of Mindanao and Aceh. Asia-Pacific Social Science Review, 5(1), 50-66. https://ejournals.ph/article.php?id=5840

Carnevale, P. J., and Arad, S. (1996). Bias and impartiality in international mediation. In J. Bercovitch (Ed.), Resolving International Conflicts: The Theory and Practice of Mediation (pp. 39-54). London: Lynne Rienner.

Che Man, W. K. (1990). Muslim separatism: The Moros of Southern Philippines and the Malays of Southern Thailand. Oxford: Oxford University Press.

Derouen, K. and Bercovitch, J. (2019). The Civil War Mediation Data Set. Bercovitch Data Centre for Conflict, Mediation, and Peacebuilding. University of Canterbury.

Elgström, O., Bercovitch, J. and Skau, C. (2003). Regional organisations and international mediation: The effectiveness of insider mediators. African Journal on Conflict Resolution, 3(1), 11-27. https://www.ajol.info/index.php/ajcr/article/view/136420

Fitrah, D. I. (2012). Multiparty Mediation in the Southern Philippines Conflict (Advanced master thesis, Leiden University, Netherlands). https://openaccess.leidenuniv.nl/handle/1887/19390

Haass, R. N. (1990). Conflicts Unending: The US and Regional Disputes. New Haven, CT: Yale University Press.

Harish, S. P. (2005). Towards Better Peace Process: A Comparative Study of Attempts to Broker Peace with MNLF and GAM. (Working Paper, Institute of Defence and Strategic Studies, Singapore). https://www.rsis.edu.sg/rsis-publication/idss/77-wp077towards-better-peace-p/\#.X6zRSC8RrUI

Heiling, R. M. (2008). Conflict resolution in Aceh in light of track one and a half diplomacy. ASEAS - Austrian Journal of South-East Asian Studies, 1(2), 171-186. https://doi.org/10.14764/10.ASEAS-1.2-12 
Higgins, N. and Daly, B. (2010). Resolving armed conflict: The Acehnese experience of mediation. US-China Law Review, 7(3), 1-14. https:/ssrn.com/abstract=2532036

Huber, K. (2004). The HDC in Aceh: Promises and pitfalls of NGO mediation and implementation. Policy Studies 9. Washington, D. C.: East-West Center Washington. https://www.eastwestcenter.org/publications/hdc-aceh-promises-and-pitfalls-ngo$\underline{\text { mediation-and-implementation }}$

Huber, K. (2008). Aceh's arduous journey to peace. In Aguswandi \& J. Large (Eds.), Accord: An international review of peace initiatives (pp. 16-21). London: Conciliation Resources. https://www.c-r.org/accord/aceh-indonesia/acehs-arduous-journey-peace

Iqbal, M. (2018, 18 July). PEACETALK: Malaysia and its role in the GPH-MILF peace process. MindaNews. https://www.mindanews.com/mindaviews/2018/07/peacetalkmalaysia-and-its-role-in-the-gph-milf-peace-process/

Karim, F. N. (2012, 21 October). SUNDAY INTERVIEW: Quiet envoy helps seal peace deal. New Straits Times. https://www.nst.com.my/nation/general/sunday-interviewquiet-envoy-helps-seal-peace-deal-1.159887

Kingsbury, D. (2006). Peace in Aceh: A Personal Account of the Helsinki Peace Process. Jakarta: Equinox.

Kivimäki, T. and Gorman, D. (2008). Non-government Actors in Peace processes: The Case of Aceh. Geneva: Centre for Humanitarian Dialogue.

Kleiboer, M. (1996). Understanding success and failure of international mediation. Journal of Conflict Resolution, 40(2), 360-389. https://doi.org/10.1177/0022002796040002007

Lederach, J. P. (1991). Of nets, nails, and problems: The folk language of conflict resolution in a Central American Setting. In K. Avruch, P. Black, \& J. A. Scimecca (Eds.), Conflict resolution: Cross-cultural perspectives (pp. 165-186). New York, Westport, Connecticut, London: Greenwood Press. https://www.beyondintractability.org/artsum/lederach-ofnets

Lingga, A. S. M. (2006). Role of Third Parties in Mindanao Peace Process. (Discussion paper, Institute of Bangsamoro, Philippines).

Marohomsalic, N. A. (2001). Aristocrats of the Malay race: A history of the Bangsa Moro in the Philippines. Quezon City: Author.

Merikallio, K. (2006). Making peace: Ahtisaari and Aceh (D. Mitchel, Trans.). Helsinki: W. Söderström.

Miller, M. A. (2008). The conflict in Aceh. In Aguswandi \& J. Large (Eds.), Accord: An international review of peace initiatives (Issue 20, pp. 12-15). London: Conciliation Resources. 
Möller, F, Derouen K. Jr., Bercovitch, J. and Wallesteen, P. (2007). The limits of peace: Third parties in civil wars in Southeast Asia 1993-2004. Negotiation Journal, 23(4), 373-391. https://doi.org/10.1111/j.1571-9979.2007.00151.x

na Thalang, C. (2017). Malaysia's role in two South-East Asian insurgencies: 'An honest broker'? Australian Journal of International Affairs, 71(4), 389-404. https://doi.org/10.1080/10357718.2016.1269147

Noble, L. G. (1981). Muslim separatism in the Philippines, 1972-1981: The making of a stalemate. Asian Survey, 21(11), 1097-1114. https://doi.org/10.2307/2643996

Odaira, T. (2009). The effectiveness of third-party mediation in internal armed conflicts: Cases of Mindanao and Aceh. The Journal of Social Science, 68, 31-52.

Sangsuwan, S. (2014). Ethnic conflict and peace process: A comparative study in Aceh and Mindanao. Political Science and Public Administration Journal, 5(1), 54-65. https://so05.tci-thaijo.org/index.php/polscicmujournal/article/view/77003

Santos, S. M. J. (2013, 15 April). The role of Islamic diplomacy in the Mindanao peace process. Asia Peacebuilding Initiatives. http://peacebuilding.asia/the-role-of-islamicdiplomacy-in-the-mindanao-peace-process/

Shea, N. (2016). Nongovernment organisations as mediators: Making peace in Aceh, Indonesia. Global Change, Peace and Security, 28(2), 177-196. https://doi.org/10.1080/14781158.2016.1162778

Smith, A. and Stam, A. (2003). Mediation and peacekeeping in a random walk model of civil and interstate war. International Studies Review, 5(4), 115-135. https://doi.org/10.1111/j.1079-1760.2003.00504011.x

Sukma, R. (2004). Security operations in Aceh: Goods, consequences, and lessons. Policy Studies 3. Washington, DC: East-West Center Washington. https://www.eastwestcenter.org/publications/security-operations-aceh-goalsconsequences-and-lessons

Sustikarini, A. (2019). Financing peace: Special Autonomy Fund as a peace dividend in Aceh, Indonesia. Journal of ASEAN Studies, 7(2), 99-121. https://doi.org/10.21512/jas.v7i2.5787

Taya, S., Omar, R., Yaacob, C. M. A. and Lantong, A. (2018). Peacebuilding model of thirdparty mediation in the Philippines: Comparing Malaysia and the OIC. The Journal of Social Sciences Research, (SPI6), 1151-1157. https://doi.org/10.32861/jssr.spi6.1151.1157

Touval, S. and Zartman, I. W. (1985). Introduction: Mediation in theory. In S. Touval \& I. W. Zartman (Eds.), International mediation and practice (pp. 7-17). Boulder, CO: Westview. 
Walter, B. F. (2002). Committing to Peace: The Successful Settlement of Civil Wars. Princeton, NJ: Princeton University Press.

Wehr, P. and Lederach, J. P. (1991). Mediating conflict in Central America. Journal of Peace Research, 28(1), 85-98. https://doi.org/10.1177/0022343391028001009

Williams, T. (2010). The MoA-AD debacle - An analysis of individuals' voices, provincial propaganda and national disinterest. Journal of Current Southeast Asian Affairs, 29(1), 121-144. https://doi.org/10.1177/186810341002900106

Young, O. R. (1967). Intermediaries: Third parties in international crises. Princeton, NJ: Princeton University Press. 